A N N A L E S

UNIVERSITATIS MARIAE CURIE-SKŁODOWSKA

LUBLIN - POLONIA

VOL. LXVII, 1

SECTIO G

2020

Uniwersytet Jana Kochanowskiego w Kielcach

JAROSŁAW CZERW

czerw@post.pl

ORCID: 0000-0003-2042-3177

\title{
Obowiązki pracowników samorządowych zatrudnionych na stanowiskach urzędniczych - zagadnienia węzłowe
}

Obligations of Local Government Employees Employed

in Clerical Positions - Nodal Issues

Znaczna liczba pracowników samorządowych, w tym w szczególności pracowników samorządowych zatrudnionych na stanowiskach urzędniczych ${ }^{1}$, powoduje, że analiza ich pozycji prawnej jawi się jako bardzo doniosła z punktu widzenia funkcjonowania całej administracji samorządowej. Jednym $\mathrm{z}$ istotniejszych elementów mających znaczący wpływ na określenie pozycji prawnej pracowników samorządowych zatrudnionych na stanowiskach urzędniczych są ich obowiązki wynikające z przepisów ustawy o pracownikach samorządowych oraz Kodeksu pracy.

Pracownikami samorządowymi są pracownicy zatrudnieni w:

1) urzędach marszałkowskich oraz wojewódzkich samorządowych jednostkach organizacyjnych,

2) starostwach powiatowych oraz powiatowych jednostkach organizacyjnych,

3) urzędach gmin, jednostkach pomocniczych gmin, gminnych jednostkach budżetowych i samorządowych zakładach budżetowych,

4) biurach (ich odpowiednikach) związków jednostek samorządu terytorialnego oraz samorządowych zakładów budżetowych utworzonych przez te związki,

1 Pracownicy samorządowi zatrudnieni na stanowiskach urzędniczych w Polsce stanowią grupę około 250 tys. osób, a każdego roku w administracji samorządowej zatrudnianych jest kilka tysięcy urzędników. Zob. Zatrudnienie w JST. Liczba urzędników rośnie najszybciej w samorządach, http://samorzad.pap.pl/depesze/wiadomosci_centralne/174335/Zatrudnienie-w-JST--Liczba-urzednikow-rosnie-najszybciej-w-samorzadach [dostęp: 19.10.2019]. 
5) biurach (ich odpowiednikach) jednostek administracyjnych jednostek samorządu terytorialnego (art. 2 ustawy z dnia 21 listopada 2008 r. o pracownikach samorządowych ${ }^{2}$ ).

Nie każdy pracownik samorządowy jest pracownikiem zatrudnionym na stanowisku urzędniczym. Ustawodawca wyróżnia bowiem oprócz stanowisk urzędniczych, w tym kierowniczych stanowisk urzędniczych, także stanowiska pomocnicze i obsługi (art. 4 ust. 2 ustawy o pracownikach samorządowych), lecz to pracownicy zatrudnieni na stanowiskach urzędniczych stanowią większość pracowników samorządowych.

Rozporządzenie Rady Ministrów z dnia 15 maja 2018 r. w sprawie wynagradzania pracowników samorządowych ${ }^{3}$ zalicza do stanowisk urzędniczych m.in. następujące stanowiska: młodszy referent, młodszy księgowy, referent prawny, referent prawno-administracyjny, referent, kasjer, księgowy, archiwista, samodzielny referent, starszy specjalista, starszy informatyk, starszy geodeta, starszy kartograf, starszy programista aplikacji, starszy projektant systemów teleinformatycznych, starszy administrator (baz danych, systemów komputerowych, zintegrowanych systemów zarządzania), starszy analityk (systemów teleinformatycznych, baz danych, sieci komputerowych), starszy konsultant do spraw systemów teleinformatycznych, inspektor, główny specjalista, starszy inspektor, informatyk urzędu, główny programista aplikacji, główny projektant systemów teleinformatycznych, główny administrator (baz danych, systemów komputerowych, zintegrowanych systemów zarządzania), główny analityk (systemów teleinformatycznych, baz danych, sieci komputerowych), główny konsultant do spraw systemów teleinformatycznych, główny specjalista do spraw legislacji, radca prawny ${ }^{4}$.

Jak podkreśla E. Ura: „Z wykonywaniem każdej pracy i każdego zawodu łączą się określone obowiązki. W odniesieniu do pracowników administracji publicznej obowiązki te wykraczają poza ramy przyjęte przepisami powszechnej regulacji Kodeksu prawa pracy"5. Obowiązki pracowników samorządowych, w tym pracowników samorządowych zatrudnionych na stanowiskach urzędniczych, określają głównie przepisy ustawy o pracownikach samorządowych oraz - w zakresie nieuregulowanym $\mathrm{w}$ ustawie o pracownikach samorządowych - przepisy Kodeksu pracy ${ }^{6}$.

2 T.j. Dz.U. 2019, poz. 1282, dalej: ustawa o pracownikach samorządowych.

3 Dz.U. 2018, poz. 936 z późn. zm., dalej: rozporządzenie w sprawie wynagradzania pracowników samorządowych.

4 Zob. załącznik nr 3 tabela II część D rozporządzenia w sprawie wynagradzania pracowników samorządowych.

5 E. Ura, Prawo urzędnicze, Warszawa 2011, s. 221.

6 Ustawa z dnia 26 czerwca 1974 r. - Kodeks pracy (t.j. Dz.U. 2019, poz. 1040 z późn. zm.). Zob. A. Szewc, T. Szewc, Komentarz do art. 24 ustawy o pracownikach samorzadowych, [w:] Ustawa o pracownikach samorzadowych. Komentarz, red. A. Szewc, Warszawa 2011, s. 192. 
Podstawowe i szczegółowe obowiązki pracowników samorządowych (w tym pracowników samorządowych zatrudnionych na stanowiskach urzędniczych) wynikają z art. 24 ustawy o pracownikach samorządowych ${ }^{7}$.

Wśród podstawowych obowiązków pracowników samorządowych ustawodawca wymienia dbałość o wykonywanie zadań publicznych oraz o środki publiczne, z uwzględnieniem interesu publicznego oraz indywidualnych interesów obywateli (art. 24 ust. 1 ustawy o pracownikach samorządowych). Jak słusznie zauważa E. Ura, obowiązek ten został określony w oparciu o ogólną zasadę postępowania administracyjnego wyrażoną w art. 7 Kodeksu postępowania administracyjnego ${ }^{8}$, zgodnie $\mathrm{z}$ którą w toku postępowania organy administracji publicznej stoją na straży praworządności, z urzędu lub na wniosek stron podejmują wszelkie czynności niezbędne do dokładnego wyjaśnienia stanu faktycznego oraz do załatwienia sprawy, mając na względzie interes społeczny i słuszny interes obywateli ${ }^{9}$. Zadania publiczne wymienione w art. 24 ust. 1 ustawy o pracownikach samorządowych to zadania należące do zakresu działania samorządu terytorialnego, określone w szczególności w art. 16 ust. 2, art. 163 i art. 166 ust. 1 i 2 Konstytucji RP ${ }^{10}$, art. 6, 7 i 8 ust. 1-2a ustawy o samorządzie gminnym $^{11}$, art. 4 ustawy o samorządzie powiatowym ${ }^{12}$ oraz art. 2 ust. 2 ustawy o samorządzie województwa ${ }^{13}$. Środkami publicznymi są natomiast: 1) dochody publiczne; 2) środki pochodzące z budżetu Unii Europejskiej oraz niepodlegające zwrotowi środki z pomocy udzielanej przez państwa członkowskie Europejskiego Porozumienia o Wolnym Handlu (EFTA); 3) środki, o których mowa w art. 3b ustawy z dnia 6 grudnia 2006 r. o zasadach prowadzenia polityki rozwoju ${ }^{14}$; 4) środki pochodzące ze źródeł zagranicznych niepodlegające zwrotowi, inne niż wymienione w pkt 2; 4) przychody budżetu państwa i budżetów jednostek samorządu terytorialnego oraz innych jednostek sektora finansów publicznych pochodzące: a) ze sprzedaży papierów wartościowych, b) z prywatyzacji majątku Skarbu Państwa oraz majątku jednostek samorządu terytorialnego, c) ze spłat pożyczek i kredytów udzielonych ze środków publicznych, d) z otrzymanych pożyczek i kredytów, e) z innych operacji finansowych; 5) przychody jednostek sektora finansów publicznych pochodzące z prowadzonej przez nie działalności

7 A. Rycak, Komentarz do art. 24 ustawy o pracownikach samorzadowych, [w:] M.B. Rycak, A. Rycak, J. Stelina, Ustawa o pracownikach samorzadowych. Komentarz, LEX/el. 2016.

8 Ustawa z dnia 14 czerwca 1960 r. - Kodeks postępowania administracyjnego (t.j. Dz.U. 2018, poz. 2096 z późn. zm.).

9 E. Ura, op. cit., s. 224.

${ }^{10}$ Konstytucja Rzeczypospolitej Polskiej z dnia 2 kwietnia 1997 r. (Dz.U. 1997, nr 78, poz. 483 z późn. zm.).

${ }^{11}$ Ustawa z dnia 8 marca 1990 r. o samorządzie gminnym (t.j. Dz.U. 2019, poz. 506 z późn. zm.).

12 Ustawa z dnia 5 czerwca 1998 r. o samorządzie powiatowym (t.j. Dz.U. 2019, poz. 511).

${ }_{13}$ Ustawa z dnia 5 czerwca 1998 r. o samorządzie województwa (t.j. Dz.U. 2019, poz. 512).

14 T.j. Dz.U. 2019, poz. 1285. 
oraz pochodzące z innych źródeł (art. 5 ust. 1 ustawy z dnia 27 sierpnia 2009 r. o finansach publicznych ${ }^{15}$ ).

Ustawodawca nie zdefiniował pojęcia interesu publicznego ani pojęcia indywidualnych interesów obywateli. Jak wyjaśnia A. Wilczyńska: „Interes można określić jako potrzebę, czyli dążenie (pragnienie) do osiągnięcia korzyści, która jest w stanie umożliwić danemu podmiotowi przetrwanie i rozwój w danym środowisku społecznym" ${ }^{16}$. Natomiast pojęcie interesu publicznego utożsamiane jest z pojęciem dobra wspólnego, a to z kolei - z Rzecząpospolitą (Rzeczpospolita Polska jest dobrem wspólnym wszystkich obywateli - art. 1 Konstytucji RP). Z kolei przez pojęcie indywidualnego interesu obywatela można rozumieć potrzebę uzyskania czy utrzymania przez niego określonej korzyści ${ }^{17}$. Jak stwierdził Sąd Najwyższy w wyroku z dnia 25 listopada 2014 r.:

Szczególny obowiązek urzędnika samorządowego służenia interesowi publicznemu (państwu polskiemu i wspólnocie samorządowej) oraz obywatelom, wyprzedza obowiązek dbałości o dobro wąsko rozumianego zakładu pracy (urzędu). Jest on bowiem przede wszystkim funkcjonariuszem publicznym wspólnoty samorządowej (gminy), będącej podstawowym składnikiem struktury państwa, w której tzw. pracodawcy samorządowi (np. urzędy) są technicznym w istocie rzeczy instrumentem realizacji interesów publicznych (wspólnoty samorządowej i państwa). W rezultacie z art. 18 ust. 1 i [art.] 24 ust. 1 ustawy z 2008 r. o pracownikach samorządowych wynika prawo i obowiązek urzędnika samorządowego ujawniania lub krytyki nieprawidłowości funkcjonowania konkretnego pracodawcy samorządowego, jeśli celem takiego działania jest ochrona interesu publicznego (państwa lub wspólnoty samorządowej) ${ }^{18}$.

Kolejne obowiązki pracowników samorządowych zostały określone w art. 24 ust. 2 ustawy o pracownikach samorządowych, zgodnie z którym do obowiązków pracownika samorządowego należą w szczególności:

1) przestrzeganie Konstytucji RP i innych przepisów prawa. Jak podkreślił Sąd Najwyższy w wyroku z dnia 10 lutego 2006 r., przestrzeganie prawa należy do podstawowych obowiązków pracownika samorządowego ${ }^{19}$. Pracownik samorządowy jest zobowiązany do przestrzegania przepisów prawa krajowego, w tym aktów prawa miejscowego oraz obowiązujących przepisów prawa międzynarodowego, w szczególności przepisów prawa Unii Europejskiej ${ }^{20}$,

2) wykonywanie zadań sumiennie, sprawnie i bezstronnie. $Z$ obowiązku sumiennego wykonywania zadań wynika dla pracownika samorządowego obowiązek wykonywania zadań według jego najlepszych intencji, jego naj-

15 T.j. Dz.U. 2019, poz. 869 z późn. zm.

${ }^{16}$ A. Wilczyńska, Interes publiczny w prawie stanowionym i orzecznictwie Trybunału Konstytucyjnego, „Przegląd Prawa Handlowego” 2009, nr 6, s. 48-55.

17 A. Rycak, Komentarz do art. 24 ustawy...

18 Wyrok SN z dnia 25 listopada 2014 r., I PK 98/14, OSN Izba Pracy 2016, nr 6, poz. 67.

19 Wyrok SN z dnia 10 lutego 2006 r., I PK 157/05, MPP 2006, nr 11, poz. 597.

20 A. Rzetecka-Gil, Ustawa o pracownikach samorzadowych. Komentarz, Warszawa 2009, s. 154. 
lepszej woli, wiedzy i doświadczenia życiowego, w sposób rzetelny i uczciwy oraz z zaangażowaniem ${ }^{21}$. Z kolei z obowiązku sprawnego wykonywania zadań wynika obowiązek wykonywania zadań wydajnie, terminowo i na wysokim poziomie. Natomiast z obowiązku bezstronnego wykonywania zadań wynika zakaz kierowania się przy wykonywaniu zadań własnymi poglądami, sympatiami i antypatiami czy partykularnymi interesami ${ }^{22}$,

3) udzielanie informacji organom, instytucjom i osobom fizycznym oraz udostępnianie dokumentów znajdujących się w posiadaniu jednostki, w której pracownik samorządowy jest zatrudniony, jeżeli prawo tego nie zabrania. Jak wyjaśnia A. Rzetecka-Gil, obowiązek ten jest sformułowany w bardzo ogólny sposób i nie uprawnia organów, instytucji i osób fizycznych do arbitralnego określania treści informacji oraz rodzaju i zakresu dokumentów ani też terminu ich udostępnienia ${ }^{23}$,

4) dochowanie tajemnicy ustawowo chronionej. Obowiązek ten uszczegóławiają obowiązujące przepisy prawa, w tym w szczególności przepisy ustawy z dnia 5 sierpnia 2010 r. o ochronie informacji niejawnych ${ }^{24}$,

5) zachowanie uprzejmości i życzliwości w kontaktach $\mathrm{z}$ obywatelami, zwierzchnikami, podwładnymi oraz współpracownikami. Pracownik samorządowy powinien zachować uprzejmość i życzliwość zarówno w stosunku do innych pracowników, jak i do obywateli. Jak wyjaśnia $Ł$. Pisarczyk: „Uprzejmość może być rozumiana jako życzliwy stosunek do ludzi, grzeczność, a nawet usłużność. Z kolei życzliwość jest utożsamiana z przyjaznym usposobieniem do innych. Uprzejmość i życzliwość wykraczają poza zwykłe zachowanie należytej staranności" ${ }^{25}$,

6) zachowanie się $\mathrm{z}$ godnością $w$ miejscu pracy i poza nim. $\mathrm{Z}$ obowiązku tego wynikają standardy zachowania pracownika samorządowego w miejscu i poza miejscem pracy, a więc także w czasie wolnym. Jak zauważa E. Ura: „Godne zachowanie się pracowników administracji publicznej oznacza godność w pełnieniu obowiązków"26. Przeciwieństwem godnego zachowania pracownika samorządowego są ,,wszelkie zachowania pracownika samorządowego, które negatywnie wpływają na wizerunek urzędu samorządowego"27,

${ }^{21}$ A. Rycak, Komentarz do art. 24 ustawy...

22 A. Szewc, T. Szewc, op. cit., s. 197.

${ }^{23}$ A. Rzetecka-Gil, op. cit., s. 155.

${ }^{24}$ T.j. Dz.U. 2019, poz. 742.

${ }^{25}$ Ł. Pisarczyk, Komentarz do art. 24 ustawy o pracownikach samorzadowych, [w:] Prawo urzędnicze. Komentarz, red. K.W. Baran, LEX/el. 2014.

${ }^{26}$ E. Ura, op. cit., s. 227.

27 Zob. P. Zuzankiewicz, Komentarz do art. 22 ustawy o pracownikach samorzadowych, [w:] W. Drobny, M. Mazuryk, P. Zuzankiewicz, Ustawa o pracownikach samorzadowych. Komentarz, Warszawa 2010. 
7) stałe podnoszenie umiejętności i kwalifikacji zawodowych. Pracownik samorządowy zobowiązany jest do stałego podnoszenia umiejętności i kwalifikacji zawodowych. W związku z tym powinien uczestniczyć w różnych formach doskonalenia zawodowego, takich jak szkolenia, kursy, seminaria czy konferencje. Obowiązek ten związany jest z określonym w art. 29 ustawy o pracownikach samorządowych obowiązkiem uczestnictwa pracowników samorządowych w różnych formach podnoszenia wiedzy i kwalifikacji zawodowych oraz obowiązkiem uwzględnienia w planach finansowych jednostek zatrudniających pracowników samorządowych środków finansowych na podnoszenie wiedzy i kwalifikacji zawodowych ${ }^{28}$.

Katalog obowiązków pracowników samorządowych określony w art. 24 ustawy o pracownikach samorządowych nie jest katalogiem zamkniętym. Wymienia on obowiązki pracowników samorządowych jedynie przykładowo. Uzupełniają go przepisy samej ustawy o pracownikach samorządowych, a także m.in. Kodeksu pracy w zakresie, jakim obowiązki te nie zostały uregulowane w ustawie o pracownikach samorządowych (art. 43 ust. 1 Kodeksu pracy) ${ }^{29}$.

Zgodnie z art. 22 § 1 Kodeksu pracy podstawowym obowiązkiem pracownika samorządowego, wynikającym z nawiązania stosunku pracy, jest obowiązek wykonywania pracy określonego rodzaju na rzecz pracodawcy, pod kierownictwem pracodawcy oraz $\mathrm{w}$ miejscu i czasie wyznaczonym przez pracodawcę. Zdaniem T. Liszcz obowiązek świadczenia pracy najczęściej można ujmować w aspekcie ilościowym (obowiązek aktywnej obecności pracownika w miejscu pracy przez określony czas oraz obowiązek wykonywania określonych zadań) oraz w aspekcie jakościowym (obowiązek dokładania przez pracownika należytej staranności przy wykonywaniu pracy) ${ }^{30}$.

Na podstawie art. $100 \S 1$ Kodeksu pracy pracownik samorządowy jest obowiązany wykonywać pracę sumiennie i starannie oraz stosować się do poleceń przełożonych, które dotyczą pracy, jeżeli nie są one sprzeczne z przepisami prawa lub umową o pracę. Zgodnie z art. $100 \S 2$ Kodeksu pracy pracownik samorządowy jest obowiązany w szczególności:

1) przestrzegać czasu pracy ustalonego w zakładzie pracy,

2) przestrzegać regulaminu pracy i ustalonego w zakładzie pracy porządku,

3) przestrzegać przepisów oraz zasad bezpieczeństwa i higieny pracy, a także przepisów przeciwpożarowych,

4) dbać o dobro zakładu pracy, chronić jego mienie oraz zachować w tajemnicy informacje, których ujawnienie mogłoby narazić pracodawcę na szkodę,

${ }^{28}$ B. Dolnicki, Samorzą terytorialny, Warszawa 2016, s. 279.

29 Ł. Pisarczyk, Komentarz do art. 24 ustawy...

30 T. Liszcz, Prawo pracy, Warszawa 2014, s. 264. 
5) przestrzegać tajemnicy określonej w odrębnych przepisach,

6) przestrzegać w zakładzie pracy zasad współżycia społecznego ${ }^{31}$.

Obowiązki pracowników samorządowych wynikające z Kodeksu pracy odnoszą się do pracowników samorządowych w takim samym stopniu jak obowiązki określone w przepisach ustawy o pracownikach samorządowych ${ }^{32}$.

Zgodnie z art. 25 ust. 1 ustawy o pracownikach samorządowych obowiązkiem pracownika samorządowego jest sumienne i staranne wykonywanie poleceń przełożonego. Według definicji zamieszczonej w Słowniku języka polskiego PWN polecenie to „wypowiedź nakazująca komuś wykonanie jakiejś czynności”’33. Polecenie przełożonego to jeden z najważniejszych instrumentów służących do kierowania procesem pracy (obok regulaminów pracy czy zakresów czynności pracowników) ${ }^{34}$. Jak stwierdził Naczelny Sąd Administracyjny w Warszawie w postanowieniu z dnia 28 marca $2018 \mathrm{r}$ :

Obowiązek wykonywania poleceń przełożonych jest obowiązkiem powszechnym w prawie pracy, występującym w każdym stosunku pracy. Obowiązek ten jest jednym z podstawowych elementów odróżniających stosunek pracy od stosunków cywilnoprawnych mających za przedmiot świadczenie pracy na podstawie umów cywilnoprawnych. Pracownik w ramach stosunku pracy jest bowiem podporządkowany na co dzień przy wykonywaniu swoich obowiązków poleceniom pracodawcy $^{35}$.

Obowiązek wykonywania przez pracownika samorządowego poleceń nie dotyczy wszystkich poleceń, a jedynie poleceń służbowych. Jak zwraca uwagę W. Góralczyk jr.:

Wystąpienie przełożonego do podwładnego, które nie mieści się w tym zakresie, nie jest poleceniem służbowym. Jeżeli polecenie służbowe wykracza częściowo poza zakres spraw służbowych, jest ono wadliwe, ale tylko w zakresie tego przekroczenia. W pozostałym jest prawidłowe i powinno być wykonane ${ }^{36}$.

Jeżeli pracownik samorządowy jest przekonany, że polecenie jest niezgodne z prawem albo zawiera znamiona pomyłki, jest on obowiązany poinformować o tym na piśmie swojego bezpośredniego przełożonego (art. 25 ust. 2 zdanie pierwsze ustawy o pracownikach samorządowych). Dopiero w przypadku pisemnego po-

31 Zob. szerzej: E. Maniewska, Komentarz do art. 100 Kodeksu pracy, [w:] K. Jaśkowski, E. Maniewska, Komentarz aktualizowany do Kodeksu pracy, LEX/el. 2018.

32 A. Szewc, T. Szewc, op. cit., s. 192.

${ }^{33}$ Hasło: polecenie, [w:] Stownik języka polskiego PWN, https://sjp.pwn.pl/szukaj/polecenie\%20.html [dostęp: 18.10.2019].

34 A. Rycak, Komentarz do art. 25 ustawy o pracownikach samorzadowych, [w:] M.B. Rycak, A. Rycak, J. Stelina, op. cit.

${ }_{35}$ Postanowienie NSA w Warszawie z dnia 28 marca 2018 r., OSK 690/18, niepubl.

36 W. Góralczyk jr., Kierownictwo w prawie administracyjnym, LEX/el. 2016. 
twierdzenia polecenia pracownik samorządowy jest obowiązany je wykonać, zawiadamiając jednocześnie kierownika jednostki, w której jest zatrudniony (art. 25 ust. 2 zdanie drugie ustawy o pracownikach samorządowych). Pracownik samorządowy nie wykonuje polecenia, jeżeli jest przekonany, że prowadziłoby to do popełnienia przestępstwa, wykroczenia lub groziłoby niepowetowanymi stratami, o czym niezwłocznie informuje kierownika jednostki, w której jest zatrudniony (art. 25 ust. 3 ustawy o pracownikach samorządowych). Odmowa wykonania poleceń, co do których pracownik samorządowy jest przekonany, że ich wykonanie prowadziłoby do popełnienia przestępstwa, wykroczenia lub groziłoby niepowetowanymi stratami, jest nie tyle uprawnieniem, co obowiązkiem pracownika samorządowego ${ }^{37}$.

Obowiązkiem pracownika samorządowego zatrudnionego na stanowisku urzędniczym, poprzedzającym podjęcie przez niego obowiązków służbowych, jest obowiązek złożenia ślubowania. Przed przystąpieniem do wykonywania obowiązków służbowych pracownik samorządowy zatrudniony na stanowisku urzędni$\mathrm{czym}^{38}$ składa w obecności kierownika jednostki lub sekretarza (sekretarza gminy, sekretarza powiatu, sekretarza województwa) ślubowanie o następującej treści: „Ślubuję uroczyście, że na zajmowanym stanowisku będę służyć państwu polskiemu i wspólnocie samorządowej, przestrzegać porządku prawnego i wykonywać sumiennie powierzone mi zadania" (art. 18 ust. 1 zdanie pierwsze ustawy o pracownikach samorządowych) ${ }^{39}$. Do treści ślubowania mogą być dodane słowa: „Tak mi dopomóż Bóg" (art. 18 ust. 1 zdanie drugie ustawy o pracownikach samorządowych). Pracownik samorządowy, składając ślubowanie, musi wiernie powtórzyć jego treść określoną przez ustawodawcę. Podobnie uważa P. Maciaszek, stwierdzając: „Ślubowanie, aby zostało ważnie złożone, musi zostać złożone zgodnie z treścią, a jeśli zostały pominięte niektóre fragmenty treści ślubowania, to uznaje się, że osoba odmawia złożenia ślubowania" ${ }^{40}$. Złożenie ślubowania warunkuje możliwość przystą̧ienia przez pracownika samorządowego zatrudnionego na stanowisku urzędniczym do wykonywania obowiązków służbowych ${ }^{41}$.

37 A. Rzetecka-Gil, op. cit., s. 163.

${ }^{38}$ Obowiązek ten zgodnie $\mathrm{z}$ art. 18 ust. 1 ustawy o pracownikach samorządowych dotyczy wszystkich pracowników samorządowych zatrudnionych na stanowiskach urzędniczych, w tym kierowniczych stanowiskach urzędniczych. W przypadku pracowników samorządowych odbywających służbę przygotowawczą, o której mowa w art. 19 ustawy o pracownikach samorządowych, ślubowanie składane jest po uzyskaniu pozytywnego wyniku egzaminu kończącego służbę przygotowawczą, przed zawarciem nowej umowy o pracę (art. 19 ust. 9 ustawy o pracownikach samorządowych).

39 B. Dolnicki, op. cit., s. 278.

${ }^{40} \mathrm{P}$. Maciaszek, Znaczenie zawarcia w rocie ślubowania niektórych funkcjonariuszy publicznych stów ,Tak mi dopomóż Bóg” w prawie polskim i prawie kanonicznym, „Przegląd Sejmowy” 2018, nr 2, s. 38. Zob. także: rozstrzygnięcie nadzorcze Wojewody Mazowieckiego z dnia 29 września 2010 r., LEX.O.LP.0911-22/10, Dz.Urz. Woj. Mazow. 2010, nr 211, poz. 7090.

${ }^{41}$ H. Szewczyk, Nawiazanie umownego stosunku pracy oraz ślubowanie pracownika samorzadowego, LEX/el. 2011. 
W przypadku odmowy złożenia ślubowania przez pracownika samorządowego zatrudnionego na stanowisku urzędniczym wygasa jego stosunek pracy (art. 18 ust. 2 ustawy o pracownikach samorządowych). Następuje to z mocy samego prawa, bez dokonywania jakichkolwiek czynności zarówno przez pracownika, jak i przez kierownika jednostki ${ }^{42}$.

Obowiązkiem pracowników samorządowych zatrudnionych na stanowiskach urzędniczych, w tym kierowniczych stanowiskach urzędniczych, jest obowiązek poddania się okresowej ocenie (art. 27 ust. 1 ustawy o pracownikach samorządowych). Okresowej oceny dokonuje bezpośredni przełożony pracownika samorządowego, nie rzadziej niż raz na 2 lata i nie częściej niż raz na 6 miesięcy (art. 27 ust. 2 ustawy o pracownikach samorządowych), najczęściej ocena taka dokonywana jest raz na rok. Jak zauważa J. Stelina: „Postępowanie w sprawie dokonywania ocen ma charakter wewnątrzzakładowy, ściśle związany ze stosunkiem pracy, ocena zaś nie jest decyzją administracyjną, lecz czynnością z zakresu prawa pracy"43. Należy zwrócić uwagę, że okresowa ocena powinna być dokonana na piśmie (art. 27 ust. 2 ustawy o pracownikach samorządowych). Po dokonaniu oceny bezpośredni przełożony niezwłocznie doręcza ocenę pracownikowi samorządowemu oraz kierownikowi jednostki, w której pracownik jest zatrudniony (art. 27 ust. 4 ustawy o pracownikach samorządowych). Okresowa ocena pracownika samorządowego dotyczy wywiązywania się przez niego z obowiązków wynikających z zakresu czynności na zajmowanym stanowisku oraz opisanych wyżej obowiązków określonych w art. 24 i art. 25 ust. 1 ustawy o pracownikach samorządowych. Pracownikowi samorządowemu od dokonanej oceny przysługuje odwołanie do kierownika jednostki, w której pracownik jest zatrudniony, w terminie 7 dni od dnia doręczenia oceny (art. 27 ust. 5 ustawy o pracownikach samorządowych). Kierownik jednostki rozpatruje odwołanie w terminie 14 dni od dnia wniesienia odwołania (art. 27 ust. 6 ustawy o pracownikach samorządowych). W przypadku uwzględnienia odwołania ocenę zmienia się albo dokonuje się oceny po raz drugi (art. 27 ust. 7 ustawy o pracownikach samorządowych). W przypadku uzyskania przez pracownika samorządowego negatywnej oceny, ponownej jego oceny dokonuje się nie wcześniej niż po upływie 3 miesięcy od dnia zakończenia poprzedniej oceny (art. 27 ust. 8 ustawy o pracownikach samorządowych). Konsekwencją uzyskania przez pracownika samorządowego ponownej negatywnej oceny jest rozwiązanie umowy o pracę, z zachowaniem okresów wypowiedzenia (art. 27 ust. 9 ustawy o pracownikach samorządowych). Jak podkreślił Sąd Najwyższy w wyroku z dnia 7 marca 2012 r.:

${ }^{42}$ M. Tomaszewska, Komentarz do art. 18 ustawy o pracownikach samorzadowych, [w:] Prawo urzędnicze. Komentarz, red. K.W. Baran, LEX/el. 2014. Zob. także: B. Sadowska, Ślubowanie i stużba przygotowawcza w samorządach, „Gazeta Samorządu i Administracji” 2016, nr 6.

43 J. Stelina, Okresowe oceny kwalifikacyjne pracowników samorzadowych, „Samorząd Terytorialny" $2007, \mathrm{nr} 7-8$, s. 17-28. 
Chociaż użycie przez ustawodawcę w art. 27 ust. 9 ustawy z 2008 r. o pracownikach samorządowych sformułowania „skutkuje rozwiązaniem umowy o pracę” mogłoby wskazywać, że rozwiązanie następuje z mocy prawa bez potrzeby składania przez pracodawcę oświadczenia woli, to takie oświadczenie jest wymagane ${ }^{44}$.

Przeciwne zdanie, którego nie podzielam, wyraził Ł. Pisarczyk, stwierdzając:

W przypadku otrzymania przez pracownika [samorządowego] ponownej negatywnej oceny okresowej umowa o pracę rozwiązuje się z zachowaniem okresów wypowiedzenia (art. 27 ust. 9 ustawy [z 2008 r. o pracownikach samorządowych]). Użycie przez ustawodawcę sformułowania „skutkuje rozwiązaniem umowy o pracę" może wskazywać, że rozwiązanie następuje z mocy prawa bez potrzeby składania przez pracodawcę oświadczenia woli ${ }^{45}$.

Kolejnymi obowiązkami pracowników samorządowych są: obowiązek złożenia oświadczenia o prowadzeniu działalności gospodarczej oraz obowiązek złożenia oświadczenia o stanie majątkowym. Zgodnie z art. 31 ust. 1 ustawy o pracownikach samorządowych pracownik samorządowy zatrudniony na stanowisku urzędniczym, w tym kierowniczym stanowisku urzędniczym, jest obowiązany złożyć oświadczenie o prowadzeniu działalności gospodarczej ${ }^{46}$. Natomiast zgodnie $\mathrm{z}$ art. 32 ust. 1 ustawy o pracownikach samorządowych na żądanie osoby upoważnionej do dokonywania czynności w sprawach z zakresu prawa pracy pracownik samorządowy zatrudniony na stanowisku urzędniczym, w tym na kierowniczym stanowisku urzędniczym, jest obowiązany złożyć oświadczenie o stanie majątkowym $^{47}$.

Konsekwencją naruszenia przez pracowników samorządowych obowiązków pracowniczych może być poniesienie przez nich odpowiedzialności porządkowej określonej przepisami Kodeksu pracy. Kierownik jednostki może zastosować w stosunku do pracownika samorządowego kary porządkowe: karę upomnienia, karę nagany lub karę pieniężną. Kary upomnienia i nagany mogą być stosowane za nieprzestrzeganie przez pracownika samorządowego ustalonej organizacji i porządku w procesie pracy, przepisów bezpieczeństwa i higieny pracy, przepisów przeciwpożarowych, a także przyjętego sposobu potwierdzania przybycia i obecności w pracy oraz usprawiedliwiania nieobecności w pracy (art. $108 \S 1$ Kodeksu pracy). Kierownik jednostki może zastosować w stosunku do pracownika samorządowego również karę pieniężną. Może to nastąpić w przypadku nieprzestrze-

44 Wyrok SN z dnia 7 marca 2012 r., II PK 155/11, OSN Izba Pracy 2013, nr 3-4, poz. 31.

${ }^{45}$ Ł. Pisarczyk, Nowa ustawa o pracownikach samorzadowych, „Praca i Zabezpieczenie Społeczne" 2009, nr 3, s. 19-27.

${ }_{46}$ Zob. na ten temat: S. Płażek, Komentarz do art. 31 ustawy o pracownikach samorzadowych, [w:] Prawo urzędnicze. Komentarz, red. K.W. Baran, LEX/el. 2014.

47 Zob. na ten temat: P. Zuzankiewicz, Komentarz do art. 32 ustawy o pracownikach samorzadowych, [w:] W. Drobny, M. Mazuryk, P. Zuzankiewicz, op. cit. 
gania przez pracownika samorządowego przepisów bezpieczeństwa i higieny pracy lub przepisów przeciwpożarowych, opuszczenia pracy bez usprawiedliwienia, stawienia się do pracy w stanie nietrzeźwości lub spożywania alkoholu w czasie pracy (art. 108 § 2 Kodeksu pracy). Jak podkreśla I. Sierocka: „Wymierzenie kary porządkowej jest dopuszczalne w razie łącznego spełnienia dwóch przesłanek, mianowicie naruszenia obowiązków pracowniczych wymienionych w art. 108 k.p. oraz winy pracownika" 48 .

Zdaniem W. Perdeusa:

Kary porządkowe nie są stopniowalne, co oznacza, że nie jest warunkiem zastosowania na przykład nagany uprzednie ukaranie upomnieniem. Pracodawca ma w tej mierze swobodę, którą ograniczają najcięższe przekroczenia porządkowe, uzasadniające wyłączność kary pieniężnej. Kary upomnienia i nagany są karami podstawowymi. Kara pieniężna jest sankcją wyjątkową ${ }^{49}$

Wskazany katalog kar porządkowych, które może zastosować kierownik jednostki w stosunku do pracownika samorządowego, jest katalogiem zamkniętym, co potwierdził Sąd Najwyższy w wyroku z dnia 26 lipca 1979 r., stwierdzając: „Artykuł 108 k.p. [...] numeratywnie wymienia tylko rodzaje kar, jakie zakład pracy może zastosować wobec pracownika" ${ }^{\circ 0}$.

Poza karami porządkowymi kierownik jednostki może zastosować w stosunku do pracownika samorządowego inne środki o charakterze dyscyplinującym (np. wypowiedzenie warunków płacy ${ }^{51}$ ), wśród których najsurowsze jest rozwiązanie umowy o pracę bez wypowiedzenia $\mathrm{z}$ winy pracownika w przypadku ciężkiego naruszenia przez pracownika samorządowego podstawowych obowiązków pracowniczych $^{52}$.

Z przeprowadzonej analizy wynika, że określony przez ustawodawcę katalog obowiązków pracowników samorządowych zatrudnionych na stanowiskach urzędniczych jest bardzo szeroki. Oprócz obowiązków, które bezpośrednio wiążą się z wykonywaną pracą, w tym obowiązków podstawowych (dbałość o wykonywanie zadań publicznych oraz o środki publiczne, $\mathrm{z}$ uwzględnieniem interesu publicznego i indywidualnych interesów obywateli) oraz obowiązków szczegółowych wynikających z przepisów ustawy o pracownikach samorządowych i Kodeksu pracy, ustawodawca przewidział szczególne obowiązki. Można do nich zaliczyć obowiązek: złożenia ślubowania, poddania się okresowej ocenie, złożenia

${ }^{48}$ I. Sierocka, Odpowiedzialność porzadkowa pracowników-odkodyfikacji do wspótczesności, „Studia Iuridica Lublinensia” 2015, nr 3, DOI: http://dx.doi.org/10.17951/sil.2015.24.3.209, s. 212.

${ }^{49}$ W. Perdeus, Komentarz do art. 108 Kodeksu pracy, [w:] Kodeks pracy. Komentarz, red. K.W. Baran, LEX/el. 2018.

${ }^{50}$ Wyrok SN z dnia 26 lipca 1979 r., I PR 64/79, OSN Izba Cywilna 1980, nr 1-2, poz. 17.

${ }_{51}$ Zob. W. Perdeus, op. cit.

${ }^{52} \mathrm{Na}$ temat odpowiedzialności porządkowej pracowników zob. szerzej: S. Kryczka, Odpowiedzialność porzadkowa, „Służba Pracownicza” 2013, nr 10, s. 5-11. 
oświadczenia o prowadzeniu działalności gospodarczej, złożenia oświadczenia o stanie majątkowym. Spośród wszystkich obowiązków to właśnie te w największym stopniu wpływają na określenie pozycji prawnej pracowników samorządowych zatrudnionych na stanowiskach urzędniczych.

\section{BIBLIOGRAFIA}

\section{LITERATURA}

Dolnicki B., Samorzad terytorialny, Warszawa 2016.

Góralczyk W. jr., Kierownictwo w prawie administracyjnym, LEX/el. 2016.

Hasło: polecenie, [w:] Słownik języka polskiego PWN, https://sjp.pwn.pl/szukaj/polecenie\%20.html [dostęp: 18.10.2019].

Kryczka S., Odpowiedzialność porzadkowa, „Służba Pracownicza” 2013, nr 10.

Liszcz T., Prawo pracy, Warszawa 2014.

Maciaszek P., Znaczenie zawarcia $w$ rocie ślubowania niektórych funkcjonariuszy publicznych słów , Tak mi dopomóż Bóg” w prawie polskim i prawie kanonicznym, „Przegląd Sejmowy” 2018, $\mathrm{nr} 2$.

Maniewska E., Komentarz do art. 100 Kodeksu pracy, [w:] K. Jaśkowski, E. Maniewska, Komentarz aktualizowany do Kodeksu pracy, LEX/el. 2018.

Perdeus W., Komentarz do art. 108 Kodeksu pracy, [w:] Kodeks pracy. Komentarz, red. K.W. Baran, LEX/el. 2018.

Pisarczyk Ł., Komentarz do art. 24 ustawy o pracownikach samorzadowych, [w:] Prawo urzędnicze. Komentarz, red. K.W. Baran, LEX/el. 2014.

Pisarczyk Ł., Nowa ustawa o pracownikach samorzadowych, „Praca i Zabezpieczenie Społeczne” $2009, \mathrm{nr} 3$.

Płażek S., Komentarz do art. 31 ustawy o pracownikach samorzadowych, [w:] Prawo urzędnicze. Komentarz, red. K.W. Baran, LEX/el. 2014.

Rycak A., Komentarz do art. 24 ustawy o pracownikach samorzadowych, [w:] M.B. Rycak, A. Rycak, J. Stelina, Ustawa o pracownikach samorzadowych. Komentarz, LEX/el. 2016.

Rycak A., Komentarz do art. 25 ustawy o pracownikach samorzadowych, [w:] M.B. Rycak, A. Rycak, J. Stelina, Ustawa o pracownikach samorzadowych. Komentarz, LEX/el. 2016.

Rzetecka-Gil A., Ustawa o pracownikach samorzadowych. Komentarz, Warszawa 2009.

Sadowska B., Ślubowanie i stużba przygotowawcza w samorządach, „Gazeta Samorządu i Administracji” 2016, nr 6.

Sierocka I., Odpowiedzialność porządkowa pracowników - od kodyfikacji do współczesności, „Studia Iuridica Lublinensia" 2015, nr 3, DOI: http://dx.doi.org/10.17951/sil.2015.24.3.209.

Stelina J., Okresowe oceny kwalifikacyjne pracowników samorządowych, „Samorząd Terytorialny” 2007, nr 7-8.

Szewc A., Szewc T., Komentarz do art. 24 ustawy o pracownikach samorzadowych, [w:] Ustawa o pracownikach samorzadowych. Komentarz, red. A. Szewc, Warszawa 2011.

Szewczyk H., Nawiazanie umownego stosunku pracy oraz ślubowanie pracownika samorzadowego, LEX/el. 2011.

Tomaszewska M., Komentarz do art. 18 ustawy o pracownikach samorzadowych, [w:] Prawo urzędnicze. Komentarz, red. K.W. Baran, LEX/el. 2014.

Ura E., Prawo urzędnicze, Warszawa 2011.

Wilczyńska A., Interes publiczny w prawie stanowionym i orzecznictwie Trybunału Konstytucyjnego, „Przegląd Prawa Handlowego” 2009, nr 6. 
Zatrudnienie w JST. Liczba urzędników rośnie najszybciej w samorządach, http://samorzad.pap. $\mathrm{pl} /$ depesze/wiadomosci_centralne/174335/Zatrudnienie-w-JST--Liczba-urzednikow-rosnienajszybciej-w-samorzadach [dostęp: 19.10.2019].

Zuzankiewicz P., Komentarz do art. 22 ustawy o pracownikach samorzadowych, [w:] W. Drobny, M. Mazuryk, P. Zuzankiewicz, Ustawa o pracownikach samorzadowych. Komentarz, Warszawa 2010.

Zuzankiewicz P., Komentarz do art. 32 ustawy o pracownikach samorzadowych, [w:] W. Drobny, M. Mazuryk, P. Zuzankiewicz, Ustawa o pracownikach samorzadowych. Komentarz, Warszawa 2010.

\section{AKTY PRAWNe}

Konstytucja Rzeczypospolitej Polskiej z dnia 2 kwietnia 1997 r. (Dz.U. 1997, nr 78, poz. 483 z późn. zm.). Rozporządzenie Rady Ministrów z dnia 15 maja 2018 r. w sprawie wynagradzania pracowników samorządowych (Dz.U. 2018, poz. 936 z późn. zm.).

Ustawa z dnia 14 czerwca 1960 r. - Kodeks postępowania administracyjnego (t.j. Dz.U. 2018, poz. 2096 z późn. zm.).

Ustawa z dnia 26 czerwca 1974 r. - Kodeks pracy (t.j. Dz.U. 2019, poz. 1040 z późn. zm.).

Ustawa z dnia 8 marca 1990 r. o samorządzie gminnym (t.j. Dz.U. 2019, poz. 506 z późn. zm.).

Ustawa z dnia 5 czerwca 1998 r. o samorządzie powiatowym (t.j. Dz.U. 2019, poz. 511).

Ustawa z dnia 5 czerwca 1998 r. o samorządzie województwa (t.j. Dz.U. 2019, poz. 512).

Ustawa z dnia 6 grudnia 2006 r. o zasadach prowadzenia polityki rozwoju (t.j. Dz.U. 2019, poz. 1285).

Ustawa z dnia 21 listopada 2008 r. o pracownikach samorządowych (t.j. Dz.U. 2019, poz. 1282).

Ustawa z dnia 27 sierpnia 2009 r. o finansach publicznych (t.j. Dz.U. 2019, poz. 869 z późn. zm.).

Ustawa z dnia 5 sierpnia 2010 r. o ochronie informacji niejawnych (t.j. Dz.U. 2019, poz. 742).

\section{ORZECZnICTwo}

Postanowienie NSA w Warszawie z dnia 28 marca 2018 r., OSK 690/18, niepubl.

Rozstrzygnięcie nadzorcze Wojewody Mazowieckiego z dnia 29 września 2010 r., LEX.O.LP.0911-22/10, Dz.Urz. Woj. Mazow. 2010, nr 211, poz. 7090.

Wyrok SN z dnia 26 lipca 1979 r., I PR 64/79, OSN Izba Cywilna 1980, nr 1-2, poz. 17.

Wyrok SN z dnia 10 lutego 2006 r., I PK 157/05, MPP 2006, nr 11, poz. 597.

Wyrok SN z dnia 7 marca 2012 r., II PK 155/11, OSN Izba Pracy 2013, nr 3-4, poz. 31.

Wyrok SN z dnia 25 listopada 2014 r., I PK 98/14, OSN Izba Pracy 2016, nr 6, poz. 67.

\section{SUMMARY}

The obligations of local government employees, including local government employees employed in clerical positions, are mainly determined by the provisions of the Act on Self-Government Employees and the provisions of the Labour Code to an extent not regulated in the Act on Self-Government Employees. Among the basic duties of local government employees, the legislator mentions: care of performing public tasks and public funds, taking into account the public interest and individual interests of citizens. The consequence of a breach of duties by self-government employees may be their liability for maintenance of order, and in the event of a serious breach of basic duties by a self-government employee it may be the termination of the employment contract without notice due to the employee's fault.

Keywords: self-government employee; employees' duties; Act on Self-Government Employees; Labour Code 


\section{STRESZCZENIE}

Obowiązki pracowników samorządowych, w tym pracowników samorządowych zatrudnionych na stanowiskach urzędniczych, określają głównie przepisy ustawy o pracownikach samorządowych oraz - w zakresie nieuregulowanym w ustawie o pracownikach samorządowych - przepisy Kodeksu pracy. Wśród podstawowych obowiązków pracowników samorządowych ustawodawca wymienia dbałość o wykonywanie zadań publicznych oraz o środki publiczne, z uwzględnieniem interesu publicznego $i$ indywidualnych interesów obywateli. Konsekwencją naruszenia przez pracowników samorządowych obowiązków pracowniczych może być poniesienie przez nich odpowiedzialności porządkowej, a w przypadku ciężkiego naruszenia przez pracownika samorządowego podstawowych obowiązków pracowniczych - rozwiązanie umowy o pracę bez wypowiedzenia z winy pracownika.

Słowa kluczowe: pracownik samorządowy; obowiązki pracownicze; ustawa o pracownikach samorządowych; Kodeks pracy 